UDC 811.111'38:801.82

\title{
Critical Thinking and Teaching Stylistic Analysis of the Literary Text
}

\author{
Valentyna Ushchyna, \\ Doctor of Philology, Professor* \\ uval@ukr.net \\ Olexander Belyakov, \\ Assistant Professor* \\ beljakov_alex@yahoo.com
}

\author{
Olena Darkevych, \\ Research Assistant* \\ darkevich@hotmail.com
}

\author{
Svitlana Kozak, \\ Research Assistant* \\ svetalucky2@gmail.com
}

*of English Philology Department, Lesya Ukrainka Eastern European National University, Lutsk, Ukraine

Received May, 1, 2018; Accepted June, 4, 2018

\begin{abstract}
The development of students' critical thinking skills is a paramount issue of modern education globally. Notwithstanding there is no accord among the philosophers, psychologists and educators as to transferability and teachability of critical thinking skills. Our approach to this issue is twofold. In order to become independent thinkers, students should be equipped with critical thinking inventory as well as have advanced practical skills of its application. This article is an attempt to look at the problem of teaching the stylistic analysis of the literary text from the perspective of critical thinking. We discuss how by the critical reading of a literary work and applying a polycritical methodology to its analysis students enhance the highorder thinking skills - analysis, synthesis and evaluation. The present paper illustrates some before, during and after reading classroom strategies that can be utilized to encourage students to dig deeper and "read between the lines" in order to decode the message of the author, effectively interpret it and use it as a vantage point for constructing intermedial connections, self-reflection and interpretation of the real world. Progressive educators create the learning environment where freedom of thought and the dissent are equally accepted and fostered. The anchoring potential of critical thinking as a mediator between the fictional and real world and as a booster of the students' abilities to evaluate, make an independent judgment and solve problems is viewed by us as a leverage on rote learning and copy-paste mentality as well as an instrument of establishing democratic values in education.
\end{abstract}

Key words: critical thinking, critical reading, polycritical methodology, literature, interpretation, BDA strategies, Frankenstein.

\section{Introduction}

Modernization of Ukrainian system of higher education in compliance with the European standards has started over a decade ago when Ukraine joined the Bologna Process in 2005. The priorities for the development of the national educational system have been 
shaped by democratic values and human rights and with the view of the competences and skills required for European citizenship, innovation and employment.

In December 2006 the European Parliament and the Council outlined the Key Competences for Lifelong Learning - A European Reference Framework (hereinafter referred to as 'the Reference Framework'). The Reference Framework sets out eight key competences: communication in the mother tongue; communication in foreign languages; mathematical competence and basic competences in science and technology; digital competence; learning to learn; social and civic competences; sense of initiative and entrepreneurship; and cultural awareness and expression (Key Competences, 2018).

Of all the themes that are applied throughout the Reference Framework (creativity, initiative, problem solving, risk assessment, decision taking, and constructive management of feelings) critical thinking comes first (ibid).

In his speech "EU cooperation on strengthening media literacy and critical thinking in education and training" Member of the European Commission for Education, Culture, Youth and Sport Tibor Navracsics signposted one of the new social and democratic challenges for the development of European educational systems: "I firmly believe that in this new era, informed and critical readers are indispensable to safeguard the pluralism and quality of the news environment that our democracies depend on. I am not saying that education is the only solution, but who can say there is a solution without education?" (Navracsics, 2017). Thus, moulding learners into informed readers well-equipped with critical thinking tools will "support young people in building their own narratives, so that they understand the principles of freedom of expression by practising it" (ibid).

To upgrade the Ukrainian system of education and implement the Reference Framework guidelines we need to train both educators and learners to critically access and evaluate the academic content and provide the experience of democratic expression and controversial issues debate within and outside the classroom. By this work we intend to prove that analytic reading of literary text may serve one of the most favored and auspicious spheres for realizing these ambitious aspirations.

There's a long tradition of using literature in the foreign language classroom. Despite the fact that as a written form literature may seem far removed from everyday communication, it has always been recognized as an effective tool in learning a foreign language (Collie and Slater, 1987; Carter and Long, 1987). At the same time the postulates of critical thinking become more and more popular in teaching as an effective way into a foreign language. But is there any connection between critical thinking and literature? Can critical thinking skills be applied in teaching a foreign language with the help of literature? These and other questions we attempt to answer in this paper.

Thus, the aim of the present article is to show that a linguistic and stylistic analysis of a literary text may serve a link between critical thinking as a methodology and literature as a valuable authentic material in the foreign language classroom. We argue that instead of merely confine itself to traditional classroom methodology in which the students closely follow the teacher's instructions, a successful language teacher should enable his or her students to exercise their critical thinking skills in interpreting a literary text. Literary texts represent a precious source of civilization 
knowledge, and the very nature of literature with its ambiguity can provide a stimulus for expressing different opinions. In literature there is no "correct" solution to how you interpret the text, and a class discussion can be genuine and interesting communication. Open-ended, multilevel literary texts can trigger the readers' responses and function as "disagreement exercises", for which the skills of critical thinking can play a useful tool.

\section{Critical thinking in education: Theoretical background}

As an indispensable part of teaching and learning process in general, critical thinking becomes even more crucial in higher education. Teaching future professionals to think independently, to analyze logically and to reason coherently can be seen as a major goal for any higher educational programme. Paul R. and Elder L. (Paul \& Elder, 2007: 2) state that students are only able to think critically when "they are consciously and deliberately thinking through some dimension of the logic of the discipline they are studying". In our case this discipline will include literature reading and linguistic interpretation of a literary text.

The use of critical thinking in education is not new. More than half a century ago Swiss psychologist Jean Piaget in his famous theory of cognitive development argued that true learning consists not in the memorization of facts, but rather in the constructing of knowledge (Piaget, 1977). But it was Socrates that much earlier demonstrated the students' inability to justify their claims with rational arguments. He taught his students to be independent thinkers, which makes his ideas still valid in the twenty first century. Critical thinking is treated here as a "pragmatic fallibilism" in Richard Bernstein's terms who argues that "fallibilism is the belief that any knowledge claim or, more generally, any validity claim - including moral and political claims - is open to ongoing examination, modification, and critique" (Bernstein, 2005: 43).

In our attempt to engage critical thinking to reading and analyzing literature we strive to arrive at what Bernstein calls "engaged pluralism" - genuine willingness to listen to others, "being vigilant against the dual temptations of simply dismissing what others are saying by falling back on one of those standard defensive ploys where we condemn it as obscure, wooly, or trivial, or thinking we can always easily translate what is alien into our own entrenched vocabularies." (Bernstein, 1992: 335). Listening to others becomes one of the most important virtues in a truly democratic community. As another American philosopher William James earlier observed in his essay "On a Certain Blindness in Human Beings", we tend to be egocentric and insensitive to the feelings, opinions, and convictions of those who are really different from us (James, 1978: 629-630). This brings us to understanding that there is no "right" or "wrong" reading of a literary text. Different people may have different views and enjoy different emotions while reading one and the same story. Critical thinking tools are meant to enable readers to appreciate various views and be eager to listen to all kinds of opinions, even if dissimilar to their own.

One of the numerous definitions of critical thinking suggests that it "is reasonable, reflective thinking that is focused on deciding what to believe or do" 
(Ennis, 1985). Paul (Paul, 1990: ii) and Siegel (Siegel, 1988: 33) define critical thinking as a process that emphasizes the examination and evaluation of information to decide its reliability or worth. According to Vincent Ruggiero, critical thinking is "the process by which we test claims and arguments and determine which have merit and which do not. In other words, critical thinking is a search for answers, a quest" (Ruggiero, 2012: 19). Then, what is education, if not a search for answers?

Critical thinking has certain qualities that are seen as important for our research. First of all, critical thinking is reflective or metacognitive - it involves thinking about your thinking. Each view, stance or opinion can be an example of thinking, but not necessarily an example of critical thinking. Critical thinking starts once one reflects on his / her thinking: Why do we have certain views? What evidence are the conclusions based on? Do other people look at the same problems differently? What are their views based on? The next significant feature of critical thinking is evidentiality. Critical thinking involves certain criteria of evidence. One can think about something accurately or inaccurately. We can use evidence that is relevant or irrelevant, or neither this nor that. Accuracy, relevance, and depth are examples of critical thinking criteria. Critical thinking is also characterized by authenticity. Critical thinking is about what you actually believe or do, it concerns your judgments. Critical thinking is most helpful when the problem is unclear (as usually happens in reading literary works). Thus, clarifying and refining are parts of critical thinking, as there is no single right answer for understanding literature. And finally, critical thinking involves being reasonable. There are no exact rules for critical thinking or reasoning. That is, there are no guarantees your reasoning would be successful, but there are guidelines that need to be followed thoughtfully. They need to be applied with sensitivity to genre, style, language, context, goals, background knowledge limitations etc.

Schafersman (Schafesman, 1991) suggests that there are generally two methods for teaching critical thinking. The first method is to simply modify one's teaching and testing methods slightly to enhance critical thinking among the students. This can be realized at the lectures, practical classes and exams through classwork, home tasks, academic essays or term papers. The second method makes use of formal critical thinking exercises, programmes and materials prepared by specialists.

Hence, there can be distinguished two different approaches to teaching critical thinking. The supporters of the first approach (Adams \& Hamm, 1999; Norris, 1992) argue that critical thinking should be taught as a separate course. While others (Ruggiero, 2012; McPeck, 1990) support teaching critical thinking as an inseparable part of other disciplines. We actually support both approaches. On the one hand, we believe that critical thinking skills can and must be taught. There should be some background instruction providing students with a formal knowledge on how to become a critical thinker. For instance, Halpern (Halpern, 2003) discusses the notion of explicit instruction in how to think. She proposes a for-part model for explicit teaching of critical thinking: dispositions for critical thinking, instruction in the skills, structure training and metacognitive monitoring. On the other hand, we consider the teachers (instructors, professors) as the main agents of development in their students critical thinking skills. As a result, students are able to analyze the content of specific subjects and apply the reasoning strategies to their academic writing. 
Although critical thinking programmes had developed significantly in the Western universities, in Ukraine they are still scarce if not absent from curricula of many schools, which makes this research timely and valid.

\section{Critical thinking and reading literature: Methodology outline}

Many scholars argue for the application of critical thinking skills in the reading and analyzing literary texts. In the analysis of different components of the text, as well as the use of stylistic and other linguistic expressive means students may confront information that appears to be inexplicable or even contradictory, and they usually have to interpret these contradictions. It is critical thinking that presupposes determining the contrarieties of various textual products, be it speeches, media articles or literary works. The ability to recognize and interpret these opposites, explaining them or finding their common features gives the students an opportunity for reconciliation the contrarieties, and thus, for better understanding the hidden meanings of the given texts.

Critical thinking tools, used in a foreign language classroom, enables readers not just to improve their language skills via dealing with the linguistic difficulties of the foreign-language literary work, but will also give them a good material for studying literature and interpreting all the complexities of the literary texts.

Reading literature, as well as talking or writing about it, is both an affective and a cognitive process. Comprehending a literary text will provide the reader with an emotional and personal experience and give room for reflection. The reader can discover important things about him/herself via the text. This emotional appeal will involve the students in a learning process.

The cognitive stimulus is catered for via an analysis of words, grammatical structures, stylistic devices and expressive means, discourse patterns, content and interpretation. Such a linguistic approach requires a higher proficiency in a target language and in theoretical linguistic disciplines, among which are lexicology, stylistics, theoretical grammar, text linguistics, discourse studies. By entering the work of fiction the learner will discover how literary effects are created through language, and he / she will see the author's conscious landing of words to convey a message. A piece of literary discourse analyzed linguistically through a lens of critical thinking skills can provide a precious analytical experience of generative value.

The development and reinforcement of critical thinking is a reciprocal doublevector process. On the one hand, the university students will not be able to evaluate the information and "decide its reliability and worth" (Esplugas \&Lundwehr, 1996: 1) unless they read literature regularly and perceptively (with a presupposition that sounds like this: by reading a piece of fiction one has to suspect each element of the text of being charged with a surplus (additional) meaning). On the other hand, the students will not be able to read a literary text or, more importantly, to read a writer if they do not possess or are unable to promptly activate their critical thinking skills (comparing, classifying, inferring, summarizing, evaluating).

That is why, at a pre-critical thinking stage, the students should be informed about the nature of fiction and be encouraged to read more literary work written by different writers. 
In addition to the above-mentioned hermeneutic circle there is another conceptual interlock between two entities: the critical thinking skills and the skills of thinking critically about literature. To put it differently, the students' abilities to identify and draw inferences, to construct and substantiate arguments, to compare and systematize, to reflect on the justification of one's beliefs and values (when extrapolating them on the significance of a belles-letters text), to connect and weigh the pros and cons of facts, ideas or a specific interpretation of a fictional text will inevitably improve their skills of thinking critically about literature. At the same time the student's critical thinking skills are boosted if when they begin to think critically, that is, to scrutinize their own assumptions, to test the evidence they collected, and if need arises, to look for counterevidence within a literary work (Barnet et al., 1996: 18). In other words, to demonstrate metacognitive awareness (Esplugas \& Lundwehr, 1996: 450).

In this context it is useful for the students to bear in mind, that in ordinary language "to criticize" usually means to find faults, but in literary studies the term does not have a negative connotation. Rather, it means "to examine carefully" (the word "criticism" comes from a Greek verb meaning "to distinguish", "to decide", "to judge"). Nevertheless, in one sense the term critical thinking does approach the usual meaning, since critical thinking requires a student to take a skeptical view of his / her response (Barnet et al., 1996: 409). The student will, as it were, argue with himself / herself seeing if his / her response can stand up to doubts.

For example, if the student says "This short story is exciting" and "that novella is boring" we have to zoom in on his or her impressionistic judgment. We can ask the student "Can you be more specific? What aspect of the novel is exciting or boring? Lack of suspense? Matter-of-fact tone? Shortage of stylistic devices? A hackneyed theme? A humorous situation? A funny outcome? By these questions we identify and recognize a problem. We actually make the first step to promote the students' skills of monitoring their own comprehension of text, that is, their skills of metacognitive activity (https://links.ed.gov). Then we can elicit answers to the following question: Is a monotonous tone of narration always a fault? Is a lack of stylistic devices a demerit of a story? Is a static plot and a mono-dimensioned and flat character always a feature that mars the literary text? This phase of critical thinking is focused on moulding the students' "generation skills (using prior knowledge beyond what is given including connecting new ideas, inferring and predicting)" (Esplugas \& Lundwehr, 1996: 3).

We will illustrate this stage of critical thinking skills by the following literary example. E. Hemingway's "Cat in the Rain" has a static plot, a monotonous style, flat characters, inexplicit conflict with a prevalence of the objective, fly-on-the wall narrator (dialogue prevails in the short story). The analysis carried out by D. Lodge, however, will puzzle a common reader and destroy her initial response to the story. The scholar offers a conjecture (and supports it by irrefutable evidence) that the indefinite article (a marker of internal focalization) at the very end of the story switches the genre of this literary work from a psychological narrative to a melodrama (Lodge, 1980). This sample of fiction helps the teacher to tap the students' background knowledge (E. Hemingway's style of omission is in the syllabus of the Course of American Literature), to interrelate the new ideas (implicative information - style narrator - syntax - diction), to make inferences (the absence of stylistic devices is a 
stylistic device; the structure in fiction is informative). The projection of these inferences onto E. Hemingway's other short stories (e.g. "The Short Happy Life of Francis Macomber") will contribute to the consolidation of the students' skills of prediction.

Our teaching experience tells us that critical thinking begins before the analysis of a particular literary text. The more so that literature-related critical thinking is a multi-perspective process.

We provide the students with an opportunity to understand fiction in the lens of pedagogical stylistics and polycritical methodology (Pryhodii \& Horenko, 2006). By this we mean the involvement of the students in the process of "guided euristics" (Pryhodii \& Horenko, 2006: 9). The students are offered a number of critical-interpretative perspectives needed to analyze a literary text. They are as follows: traditional approach (historical-biographical and moral-philosophical); the formalistic approach; the psychological approach; mythological and archetypal approach; feminist approach, structuralism and poststructuralism, cognitive stylistics (Guerin et al., 1992).

A polycritical interpretation allows the teacher to train a student as an active reader who will, hopefully, be able to have a conversation with the text and, through that text, with the author. The student-reader asks questions of the text and then looks for the answers the text may give. For example, how will "Eveline" from Joyce's eponymous story escape from religious and parental repressions? What is the effect of telling the story by a "We"-narrator in W. Faulkner's "A Rose for Emily"? What does the author mean by "faith" in N. Hawthorne's "Young Goodman Brown"?

We have revolved six criteria to differentiate these critical approaches to fiction: (1) the content of interpretation; (2) the function of the reader; (3) the function of the author (narrator); (4) the key concepts the proponents of each critical approach are operating, (5) advantages and disadvantages of each approach.

The instructor may begin with a short story and then analyze it from the standpoint of each of the above critical approaches. Another possible use of a polycritical methodology is to have students read several literary works and brainstorm them in class with due regard to a pertinent critical approach. This double exposure has the advantage of creating a sense of discovery that awaits a perspective reader.

Their activity allows the teacher to integrate the core critical thinking skills into a literary analysis of a prose work: the students use their identifying and recognizing skills when they detect the criteria of the above-interpretative approaches in a literary text; the students develop their remembering skills when they restore in their memory the characteristics of the critical approaches they resort to; the students' analyzing skills are upgraded when they classify and compare the features of two or more short stories or reveal the disparities between them; the students do not only use prior knowledge of the material they have learnt but also may generate new insights to bear on both the literature read earlier and on subsequent readings. The students' evaluating skills are improved when they juxtapose the positive and negative aspects of each of the approaches.

We acknowledge that individual students bring their own unique experiences and emotions to the perception of a literary work of art. Their potential for critical thinking is also different. This, however, cannot impede their progress in mastering their skills of critical 
thinking provided that they rejad heterogeneous (in terms of style, genre and content) literature and employ a multi-faceted approach of a literary text.

\section{Analysis and Discussion}

The educators have long come to a consensus that acquisition of critical thinking skills is the desired outcome of any learning process. In the traditional approach to studying literature a pivotal role in understanding literary texts is ascribed to reading which is seen as a transaction between the reader's prior knowledge and the ideas incorporated into the text. The potential problems arising from that routine can be roughly outlined as follows:

1) What is the structure of the reader's prior knowledge? In what way can the educators contribute to the construction of it?

2) How to actualize the reader's interaction with the text?

3) How to assess understanding of the text?

Evidently the posed questions are closely aligned with before, during and after (BDA) reading strategies. Typically, the first two are considered as low-order thinking (knowledge, comprehension, application), according to Bloom's taxonomy (Figure 1), as opposed to after reading strategies which involve higher-order thinking (analysis, synthesis, evaluation).

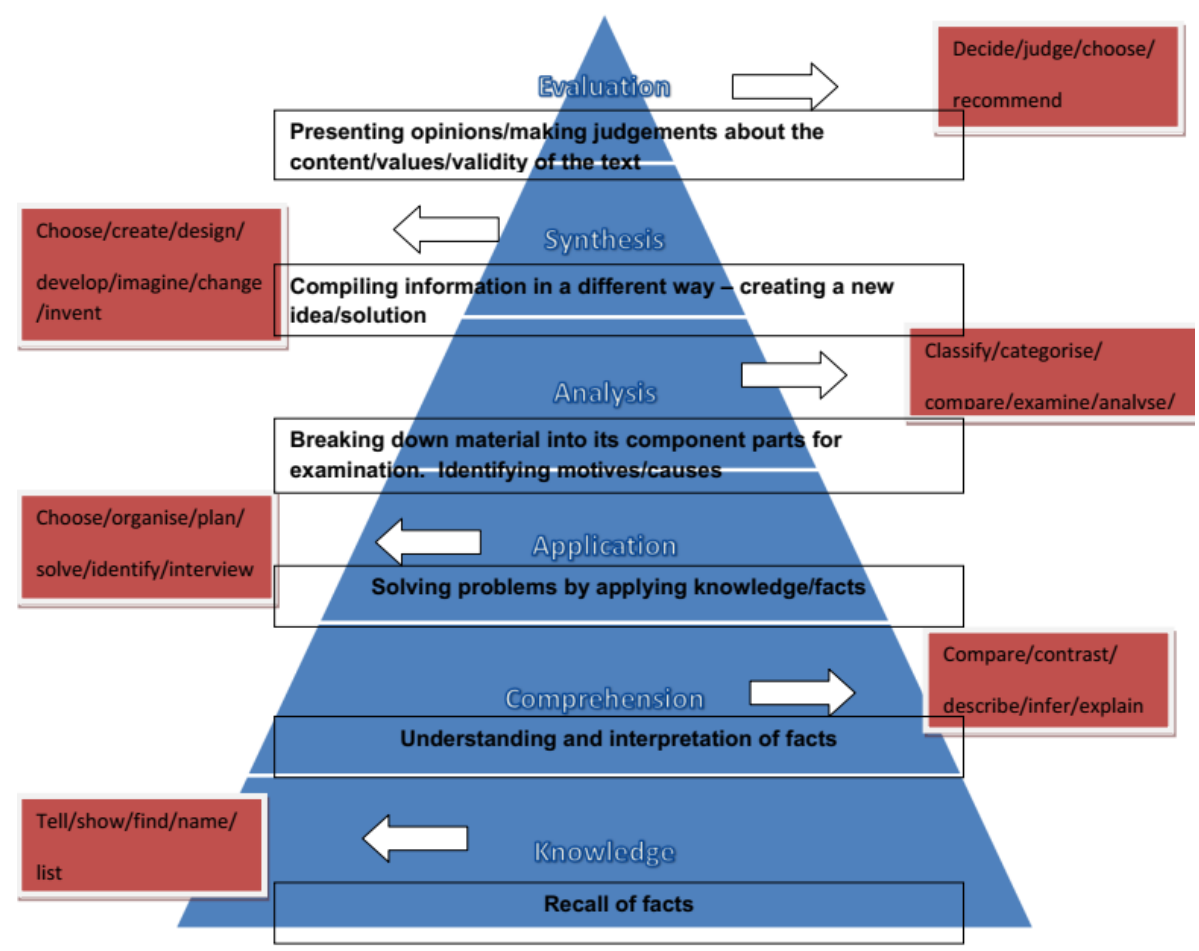

Figure 1. Bloom's Taxonomy: The Cognitive Process Dimension 
Our stance on the application of critical thinking skills in studying literature is clear: it is a cross-cutting process that encompasses all BDA strategies.

The idea of Hans Robert Jauss that the reception of a literary work can be assessed within an "objectifiable system of expectations that arises for each work in the historical moment of its appearance, from a pre-understanding of the genre, from the form and themes of already familiar works, and from the opposition between poetic and practical language" (Jauss, 1982: 22) constitutes the framework for before reading strategies suggested in this paper. Readers' expectations are conditioned but not limited by their epistemic background, disposition and motivation. However, this roadmap for successful comprehension, decoding and appraisal of a literary text is incomplete without the guiding role of the educator aimed at activation and enhancement of the readers' prior knowledge. Iser (Iser, 1974) maintains that "In this way the reader is forced to discover the hitherto unconscious expectations that underlie all his perceptions, and also the whole process of consistency-building as a prerequisite for understanding" (Iser, 1974). The prereading tasks are tailored to prepare the readers to perceive the symbols, allusions, themes, motifs, etc. of the literary work, distinguish, interpret and evaluate verbal and non-verbal characteristics of the text.

To illustrate the application of conceptual framework of this paper we have chosen the novel "Frankenstein" by Mary Shelley which is generally acknowledged as a landmark of both romantic and gothic fiction as well as a pioneering science fiction novel.

\section{Before reading activities}

\section{Formation of historical and cultural awareness}

1. Students are suggested to inquire into the main ideas postulated in John Locke's "Essay Concerning Human Understanding" (Locke, 1689) and Jean Jacques Rousseau's "Emile, or On Education" (Rousseau, 1762). They are asked to zoom in on the patriarchal system and educational theories the philosophers reflect on in their works. The next step is writing a brief summary (1-2 sentences) synthesizing the major notions of the articles. Further, the student's notes are organized into two mind maps - "Lock's theory" and "Rousseau's theory". Discussing the ideas contemporary to Mary Shelley and deducing their relation to "Frankenstein" pursue the development of the skills to define, outline, organize, examine, judge and predict and has a deeper level of understanding the "big idea" of the novel as its result.

2. To generate the readers' interest, build connections, minimize the gulf of the "horizons of expectations" (Jauss, 1982) we find it appropriate to assign the modern text prior to introducing students to a more challenging classic novel. "Harry Potter and the Philosopher's Stone" (Rowling, 1998) and "Frankenstein" are intrinsically connected by the legend of the "Philosopher's Stone". Students have to research the topic and produce a multi-media presentation (PPT/podcast/video) that conveys the appeal and dangers of the Philosopher's Stone. 
3. "The Modern Prometheus" is the subtitle of the novel under discussion. Percy Shelley (Mary Shelley's husband) wrote a four-act lyrical drama titled "Prometheus Unbound" (1820). Students delve into Prometheus mythology and Shelley's mythmaking, create the web of ideas pertinent to both sources, make assumptions as to their relevance to "Frankenstein".

4. Students produce "A Book of Knowledge" that bears the description of the late $18^{\text {th }}$-early $19^{\text {th }}$ century scientific practices and includes their critical views on these experiments and endeavours in the light of modern science. The chapters may include Galvanism, Body snatching, Vivisections, Polar Expeditions, etc.

Other tasks can deal with the analysis of feminist ideas (Shelley, 1792), survey/webquest of Frankenstein legend in arts (literature/music/painting/ cinematography), exploration of the biography of the novelist (writing a monodrama), the study of the novel setting (creating a travel brochure), etc.

\section{Formation of prior knowledge through the exploration of the genre}

1. Students are asked to describe Caspar David Friedrich's painting "Wanderer above the Sea of Fog" (1818). The focus is on emotional response evoked by the magnificence of nature. Suggested questions: What mental images does the painting elicit? How is the physical isolation of the central figure associated with the spiritual isolation? In what way is the reverence for nature expressed by the great poet of Romanticism William Wordsworth related to the painting?

"...well pleased to recognise

In nature and the language of the sense

The anchor of my purest thoughts, the nurse,

The guide, the guardian of my heart, and soul

Of all my moral being." (Wordsworth, 1798)

Students' ideas are organized into a radial diagram representing the features of Romanticism they outlined inductively. The educator's role is to verify the notions and ensure they embrace individualism and alienation; spontaneity and the impulses of feeling; reverence for nature, seen as imbued with the spirit of God and unsullied by man; the glorification of the ordinary; the supernatural, the romance, and psychological extremes; the cult of the child (Maunder, 2010; Abrams, 2005).

2. Students are requested to recall horror stories/novels/films they have read or seen. Working collectively they create a Venn-diagram of the typical features of Gothicism. The teacher should make certain that it includes the setting, the bleak and ominous atmosphere, mystery, suspense, foreboding, the supernatural, the macabre, the altered psychological states, and the archetypal characters (a villain, a damsel in distress, a saviour, a clergyman).

\section{Formation of prior knowledge through the language}

1. To encourage student predictions and use of figurative language, the teacher provides the list of words from the actual text related to Frankenstein's monster. Students have to write a "probable description" of the creature. Having read the book, they can compare their preconception of the monster's image with the one from the novel. The list 
might include features, muscles, arteries, lustrous, whiteness, complexion, horrid, beautiful, yellow, contrast, colour, proportion, luxuriance.

2. To elicit students' judgment of the tone, lexical and syntactical complexity of the novel, the teacher compiles a collection of significant quotes from the novel. The students analyze the excerpts and comment on them. In advanced/proficiency level classes students try to rewrite the passages in the style of the authors from different literary epochs. For instance, "It is with considerable difficulty that I remember the original era of my being; all the events of that period appear confused and indistinct. A strange multiplicity of sensations seized me, and I saw, felt, heard, and smelt at the same time; and it was, indeed, a long time before I learned to distinguish between the operations of my various senses. By degrees, I remember, a stronger light pressed upon my nerves, so that I was obliged to shut my eyes." (Shelley, 2003).

\section{Formation of prior knowledge through preliminary consideration of themes}

1. The dangers of science. Students are assigned to write a blog entry in response to Prof. Lewis Wolpert's article "Is Science Dangerous?" (Wolpert, 2002). They can choose to highlight a specific topic (the ethics of science, genetic engineering, cloning, GMO, humanoid robots, etc.) and are expected to express their opinion on the issue of social, moral and ethical obligations of scientists.

2. Doppelgängers. Students have to do some research and outline in a chart the differences between Doppelgänger, Foil, and Alter Ego, add the examples in literature, quotations from literary works to illustrate the point, and their comments.

3. Parental responsibility. To build personal connection, promote students' thinking and help them focus on significant themes tackled in the novel the teacher prepares Anticipation Guide and elicits students' opinions on the following statements:

- It is a parent's job, more than society's, to nurture his/her child.

- With the advent of genetic engineering and "designer" babies, parents now have less important roles in the birth process.

- All children are innately good.

- Every child needs "mothering" in order to become "human."

- All parents love their children unconditionally, no matter how they look or act.

- Children who are "deformed" physically or mentally should be isolated from society (Mayer, 2009).

\section{During reading activities}

At the initial stage of during reading strategies application students are engaged in the procedure of gathering information about what, where, when and who. Celia Esplugas (Esplugas \& Lundwehr, 1996) maintains that the narrator is "the text's most complex narrative element". In view of this, we will specifically focus on tackling the how-questions, that is the analysis of the narrative and the effect the writer's choice of the narratorial stance has on the receiver. 
Marry Shelley excels in enthralling the readers by enabling them to become active participants in interpreting, evaluating and creating a sufficient insight into the structure of her narrative since the familiar and reliable narrator who knows, explains, decodes everything is eliminated. Instead, she employs the Chinese box technique embedding three narratives into one another. Students create a diagram to visualize the basic narrative structure. As they proceed with the analysis and interpretation of the novel they are expected to notice that the epistolary form and the triangular narrative create a multidimensional and multifunctional artistic domain in which the voices of the characters, narrators and readers overlap.

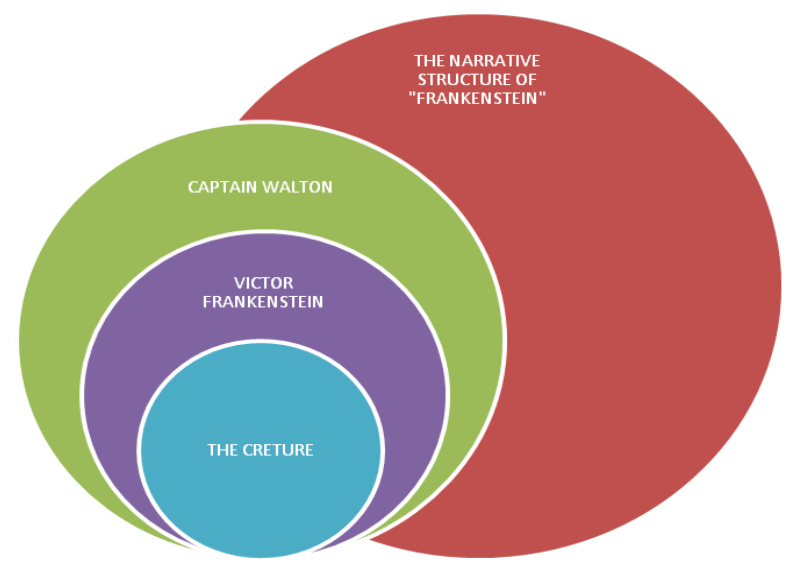

Figure 2.The Narrative Structure of "Frankenstein"

The frame of "Frankenstein" is constituted by the letters that Captain Robert Walton, the explorer of the North Pole, sends to his sister, MrsSaville, in England. These letters open and close the novel. Within these letters, the reader, together with Walton's sister, reads the bizarre narrative of Victor Frankenstein and, within Victor's narrative, the narrative of the Creature. What contributes to the complexity of the narratorial technique is that the narrative of the Creature incorporates two different perspectives: Victor's account of the Creature and the Creature's direct confession to Walton. Therefore, what MrsSaville reads is Victor's doubly mediated story (first Victor's version and then Walton's account of Victor's story) and the Monster's triply mediated story (first Victor's version, next the Monster's direct account, and then Walton's narration of the Monster's story). Each narrator tells $a$ version of the story, not the story, hence the responsibility of interpreting the text and judging its credibility is obviously shifted to the readers challenging their critical thinking skills.

Advanced and proficiency level students can be introduced to the concept of deictic projections in the literary text. That would enable them to describe and track the switching between the narrative modes through the manifestations of prototypical deictic categories.

For a detailed analysis of tropes and figurative language students are assigned carefully selected abstracts from the novel. They have to demonstrate a pragmaticallyoriented approach to the analysis of the stylistic devices while not merely identifying them but attempting to determine their communicative function and estimate their 
overall effect. In the process of decoding metaphors, metonymies, irony, symbols, hyperboles, litotes, etc. the readers are expected to identify the difference between the explicatures and implicatures and produce their unique interpretation of the text. Peter Stockwell claims that stylistics can be used "as a means of demystifying literary responses, understanding how varied readings are produced from the same text; and it can be used to assist in seeing features that might not otherwise have been noticed. It can shed light on the crafted texture of the literary text, as well as offering a productive form of assistance in completing interpretations, making them more complex and richer. Stylistics can thus be used both as a descriptive tool and as a catalyst for interpretation."

The following excerpt from the novel is a relevant example as it contains various points for stylistic analysis and discussion.

"I entered the room where the corpse lay and was led up to the coffin. How can I describe my sensations on beholding it? I feel yet parched with horror, nor can I reflect on that terrible moment without shuddering and agony. The examination, the presence of the magistrate and witnesses, passed like a dream from my memory when I saw the lifeless form of Henry Clerval stretched before me. I gasped for breath, and throwing myself on the body, I exclaimed, "Have my murderous machinations deprived you also, my dearest Henry, of life? Two I have already destroyed; other victims await their destiny; but you, Clerval, my friend, my benefactor-"

The human frame could no longer support the agonies that I endured, and I was carried out of the room in strong convulsions.

A fever succeeded to this. I lay for two months on the point of death; my ravings, as I afterwards heard, were frightful; I called myself the murderer of William, of Justine, and of Clerval. Sometimes I entreated my attendants to assist me in the destruction of the fiend by whom I was tormented; and at others I felt the fingers of the monster already grasping my neck, and screamed aloud with agony and terror. Fortunately, as I spoke my native language, Mr. Kirwin alone understood me; but my gestures and bitter cries were sufficient to affright the other witnesses.

Why did I not die? More miserable than man ever was before, why did I not sink into forgetfulness and rest? Death snatches away many blooming children, the only hopes of their doting parents; how many brides and youthful lovers have been one day in the bloom of health and hope, and the next a prey for worms and the decay of the tomb! Of what materials was I made that I could thus resist so many shocks, which, like the turning of the wheel, continually renewed the torture?" (Shelley, 2003)

Leech and Short (Leech \& Short, 2007) suggest a comprehensive scheme for analysis of a literary text or as they call it "a checklist of linguistic and stylistic categories" which includes lexical categories, grammatical categories, figures of speech, and cohesion and context. They conclude that "The discovery that varied aspects of a writer's style point towards a common literary purpose is something that can only be demonstrated through the details of stylistic analysis." 


\section{After reading activities}

These activities encourage students to make inferences and generalizations, corroborate and review their ideas, deepen their interpretation of "Frankenstein", boost applied comprehension, facilitate building text-to-text, text-to-self and text-to- world connections. Mark Sadoski (Sadoski, 2004) asserts that "The goal of independence in reading is more than academic. This goal is critical to the growth of a democratic society with a citizenry that can become informed for themselves rather than depending on press releases or canned commentary. It is critical to experiencing the life of the mind and the life of the heart in all their richness; to grow in understanding, feeling, and wisdom; to truly become all that we have the right to become."

\section{Creative writing}

1. To develop the students' critical thinking skills to modify and invent the educator assigns writing alternative endings to the novel.

2. Since "Frankenstein" is an epistolary novel, students write a letter to the author, to one of the characters, to one character from another. They can experiment with different points of view and writing styles.

3. Students write a cinquain/haiku/limerick about a character.

\section{Group and individual projects}

1. Time machine. Students elaborate on possible reactions, attitudes and outcomes imagining Victor Frankenstein as a modern scientist. The activity can be done in the form of a TV talk-show with the host-moderator, the characters from the novel performing the roles of the invited guests and the audience actively participating by asking challenging questions.

2. Students create a book trailer for the novel. They can vary their productions in accordance with the target audience, the style (newsreel, commercial, etc.).

3. Students create a collage around the major themes or characters of the literary work.

\section{Building connections}

1. "Frankenstein" has inspired numerous film adaptations. Students delineate the criteria and compare/contrast the book and a screen version.

2. Students choose a novel or a play in which a character alienated from the culture or society because of gender, race, class, creed or ambition plays a significant role and discuss how that character's alienation reveals the surrounding society's assumptions or moral values.

3. An ample number of literary works focus on themes of scientific ethics, doppelgängers and gender roles. To mention a few20th-21st century classics: 


\author{
Aldous Huxley. Brave New World (1932) \\ Daniel Keyes. Flowers for Algernon (1966) \\ Margaret Atwood. The Handmaid's Tale (1985) \\ David Mitchell. Cloud Atlas (2004) \\ Suzanne Collins. Hunger Games(2008) \\ Dave Eggers. The Circle (2013)
}

Students can be assigned to read one of them individually or as a group. They can also compile their own list of extended reading. As a possible outcome of this activity students will be able to design a Reciprocal Knowledge Exchange Network. Large sheets of paper pre-labelled with the book titles are posted on the classroom wall. Students brainstorm, write down the major themes (adding textual evidence to support their ideas is optional), and using paper pins and thread create a web of generic themes.

\title{
Conclusion
}

Learning by rote has a deep-rooted tradition in the Ukrainian system of education with memorization, drilling and brute repetition being constituent elements of the rigid teaching/studying routine. In the classroom where mechanical learning without proper understanding and reflection is preferred to creativity, innovation and independent thinking, there is no place for reasoning, comprehension of relationships involved in the material or its potential for the real-life problem-solving.

A powerful instrument we deem appropriate to combat the fossilized methodology is critical thinking. It should become modus operandi of both educators and educatees. As Bell Hooks (Hooks, 2010) rightly states "The most exciting aspect of critical thinking in the classroom is that it calls for initiative from everyone, actively inviting all students to think passionately and to share ideas in a passionate, open manner. When everyone in the classroom, teacher and students, recognizes that they are responsible for creating a learning community together, learning is at its most meaningful and useful. In such a community of learning there is no failure. Everyone is participating and sharing whatever resource is needed at a given moment in time to ensure that we leave the classroom knowing that critical thinking empowers us."

Studying and analyzing literature is both an intellectual exercise and a challenging experience for the ambitious goal pursued by both is to understand how life works. While exploring the microcosm of the literary works we explore the microcosm of our own selves and at the same time the macrocosm of the outer world that exists beyond the pages of the book.

By utilizing critical thinking we are able to substantiate our stance, provide evidence, secure and verify our judgments. Independent thinkers acknowledge their strengths and weaknesses, think analytically and objectively, present well-constructed arguments and are open-minded to the ideas and views of other (Judge et al., 2009).

We live in the age of high technologies, 24-hour television, mobile phones and the Internet. An average person has to process a torrent of information all kinds of media bombard them with. The study of DrMartin Hilbert (Hilbert, 2012) and his team at the University of Southern California reveals that we now receive five times as much information every day as we did in 1986 - the equivalent of 175 newspapers. Enhanced 
critical thinking skills endow us with the ability to sift through the gulf of data, avoid our opinions being manipulated our decisions being nudged. Thus, critical thinking is vitally important to maintain democratic values in education and overall in the society.

\section{References}

Abrams, Meyer Howard. 2005. The Norton Anthology of English Literature. Edited by Stephen Greenblatt. 8th ed. Volume 2. New York: Norton \& Company.

Dennis M. Adams, Mary E. Hamm. 1990. Cooperative Learning: Critical Thinking and Collaboration across the Curriculum. Springfield, Il.: Charles C. Thomas Publisher.

Barnet, Sylvan, Berman, Morton, Burto, William, Stubbs, Marcia. 1996. Literature for Composition: Essays, Fiction, Poetry, and Drama. 4th edition. New York: Harper Collins College Publishers.

Bernstein, Richard J. 1992. The New Constellation: Ethical-Political Horizons of Modernity/Postmodernity. Cambridge, Massachusetts: MIT Press.

Bernstein, Richard J. 2005. The Abuse of Evil: The Corruption of Politics and Religion since 9/11. Cambridge, Malden: Polity Press.

Bobkina, Jelena, and Stefanova, Svetlana. 2016. Literature and critical literacy pedagogy in the EFL classroom: Towards a model of teaching critical thinking skills. Studies in Second Language Learning and Teaching, 6 (4): 677-696.

Carter, Ronald, and Long, Michael L. 1987. The Web of Words: Exploring Literature through Language. Cambridge: Cambridge University Press.

Collie, Johanne, and Slater, Steven. 1987. Literature in the Language Classroom. Cambridge: Cambridge University Press.

Ennis, Robert. H. 1985. A logical basis for measuring critical thinking skills. Educational Leadership, 43(2): 44-48.

Esplugas, Celia, and Lundwehr, Margarete. 1996. The Use of Critical Thinking Skills In Literary Analysis. WestChester University. Foreign Language Annals.

Guerin, Wilfred, Labor, Earle, Morgan, Lee, Reesman, Jeanne, and Willingham, John. 1992. A Handbook of Critical Approaches to Literature. 3rd Edition. New York, Oxford: Oxford University Press.

Halpern, Diane. F. 2003. Thought and Knowledge: An Introduction to Critical Thinking ( $4^{\text {th }}$ edition). New Jersey: Elbaum, Mahwah.

Hilbert, Martin. 2012. How much information is there in the "information society"? Accessed May 3, 2018. https://rss.onlinelibrary.wiley.com/doi/full/10.1111/j.17409713.2012.00584.x

Hooks, Bell. 2010. Teaching critical thinking: practical wisdom. Routledge Taylor \& Francis Group. New York and London.

Iser, Wolfgang. 1974. The implied reader: Patterns of communication in prose fiction from Bunyan to Beckett. Baltimore: The Johns Hopkins University Press.

James, W. 1978. The Writings of William James: A Comprehensive Edition. Chicago: University of Chicago Press.

Jauss, Hans Robert. 1982. "Literary history as a challenge to literary theory". In Toward an Aesthetic of Reception, 3-45. Minneapolis: University of Minnesota Press.

Judge, Brenda, Jones, Patrick, and McCreery, Elaine. 2009. Critical Thinking Skills for Education Students. Learning Matters. Publisher Sage Publications Ltd; Imprint Learning Matters Ltd. 
Key Competences for lifelong learning. Recommendation of the European Parliament and of the Council. December 18, 2006. Accessed April 29, 2018. http://eurlex.europa.eu/LexUriServ/LexUriServ.do?uri=OJ:L:2006:394:0010:0018:en:PDF.

Leech, Geoffrey, and Short, Mick. 2007. Style in Fiction. A Linguistic Introduction to English Fictional Prose, 61-64. 2nd edition. Pearson Education Limited.

Locke, John. 1689. The Works of John Locke, vol. 1 (An Essay concerning Human Understanding Part 1). http://oll.libertyfund.org/titles/locke-the-works-vol-1-an-essayconcerning-human-understanding-part-1.

Lodge, David. 1980. Analysis and Interpretation of the Realistic Text: A Pluralistic Approach to Ernest Hemingway's "Cat in the Rain", 5-22. Poetics Today 1. no. 4. Narratology II: The Fictional Text and the Reader.

Maunder, Andrew. ed. 2010. Encyclopedia of literary romanticism. Facts On File, Inc. An imprint of Infobase Publishing.

Mayer, Laura Reis. 2009. A Teacher's Guide to the Signet Classics Edition of Mary Shelley's Frankenstein. Penguin Group (USA)

McPeck, John. 1990. Teaching Critical Thinking: Dialogue and Dialectic. New York: Routledge.

Navracsics, Tibor. 2017. EU cooperation on strengthening media literacy and critical thinking in education and training. Accessed April 26, 2018. https://ec.europa.eu/commission/commissioners/2014-2019/navracsics/announcements/eucooperation-strengthening-media-literacy-and-critical-thinking-education-and-training_en).

Norris, Steven. 1992. Introduction: The Generalizability Question, 1-5. In: Steven Norris, Ed. The Generalizability of Critical Thinking: Multiple Perspectives of an Educational Ideal. New York: Teachers College press.

Paul R., and Elder L. 2007. "Critical thinking: The art of Socratic questioning." Journal of Developmental Education 31, no. 1: 34-35.

Paul, Richard. 1990. Critical Thinking: What Every Person Needs to Survive in a Rapidly Changing World. Rohnert Park, CA: Center for Critical Thinking and Moral Critique.

Piaget, Jean. 1977. "The role of action in the development of thinking". In Knowledge and development, 17-42. Springer US. Lybid.

Pryhodii, Serhii, Horenko, Olena. 2006. Amerykanskyi romantyzm. Polikrytyka. Kyiv:

Rousseau, Jean-Jacques. 1762. Emile, or Education. Accessed April 28, 2018. http://oll.libertyfund.org/titles/rousseau-emile-or-education

Rowling J. K. 1998. Harry Potter and the Philosopher's Stone. Published by Bloomsbury Publishing PLC.

Ruggiero, Vincent Ryan. 2012. Beyond Feelings. A Guide to Critical Thinking. $9^{\text {th }}$ Edition. New York: McGraw Hill.

Sadoski, Mark. 2004. Conceptual foundations of teaching reading. New York-London: The Guilford Press.

Schafesman, S. D. 1991. An Introduction to Critical Thinking.Internet Resource. Accessed April 25, 2018. http://www.freeinquiry.com/critical-thinking.html.

Shelley, Mery. 1792. A Vindication of the Rights of Woman. https://www.bl.uk/collection-items/mary-wollstonecraft-a-vindication-of-the-rights-ofwoman. Kingdom.

—. 2003. Frankenstein. Penguin Classics. Published by Penguin Books Ltd, United

Shelley, Percy Bysshe. Prometheus Unbound. https://andromeda.rutgers.edu/ jlynch/ Texts/prometheus.html. 
Siegel, Harvey. 1988. Educating Reason: Rationality, Critical Thinking and Education. New York: Routledge, Chapman and Hall.

Stockwell, Peter. Stylistics: retrospect and prospect. https://www.academia.edu/ 718961/Stylistics_retrospect_and_prospect.

Wolpert, Lewis. 2002. Is Science Dangerous? Nobel Symposium (NS 120). "Virtual Museums and Public Understanding of Science and Culture". https://www.nobelprize.org/nobel_organizations/nobelfoundation/publications/symposia/ns1 20-lectures/wolpert.pdf.

Wordsworth, William. 1798. Lines Composed a Few Miles above Tintern Abbey, On Revisiting the Banks of the Wye during a Tour. https://www.poetryfoundation.org/ poems/45527/lines-composed-a-few-miles-above-tintern-abbey-on-revisiting-the-banks-ofthe-wye-during-a-tour-july-13-1798. 